\title{
Acorn storage in tree cavities by Eurasian jay (Garrulus glandarius L.)
}

\author{
Aleksandra Wróbel ${ }^{1}\left[\right.$ D $\cdot$ Przemysław Kurek ${ }^{2}$ (D) Dorota Dobrowolska $^{3}[$ \\ Received: 19 March 2021 / Revised: 12 April 2021 / Accepted: 20 April 2021 / Published online: 28 April 2021 \\ (c) The Author(s) 2021
}

\begin{abstract}
Seed hoarding by granivorous animals requires cache-protection strategies which allow to protect hoarded seeds against pilferage. This study reports the first case of acorn hoarding in tree cavities by Eurasian Jays (Garrulus glandarius). Out of 116 removed acorns of both pedunculate oak (Quercus robur) and Northern red oak (Q. rubra), we localized 14 consumed and 102 stored acorns. Five experimental acorns (4.9\% of stored acorns) were found stored in tree cavities. The notion that hoarding seeds in tree cavities may constitute a cache-protection behavior of Eurasian Jays represents a working hypothesis that ought to be tested in future studies.
\end{abstract}

Keywords Acorn dispersal · Granivorous bird · Quercus · Radio-tracking · Seed hoarding · Tree cavities

\section{Zusammenfassung}

Eichelhäher (Garrulus glandarius L.) horten Eicheln in Baumhöhlen Das Horten von Samen durch körnerfressende Tiere erfordert Strategien zum Schutz vor Räubern. Diese Untersuchung berichtet über den ersten Fall von Eichel-Lagerung in Baumhöhlen beim Eichelhäher (Garrulus glandarius L.). Von 116 entnommenen Eicheln sowohl der Stileiche (Quercus robur) als auch der nördlichen Roteiche (Quercus rubra) fanden wir 14 verzehrte und 102 eingelagerte Eicheln. Fünf Versuchseicheln (das waren 4,9\% der eingelagerten Eicheln) wurden in Baumhöhlen gefunden. Die Annahme, das Horten von Eicheln in Baumhöhlen sei eine Schutzstrategie von Eichelhähern, ist eine Arbeitshypothese, die in zukünftigen Studien überprüft werden sollte.

\section{Introduction}

Many large-seeded trees have established strongly mutualistic interactions with granivores, where trees are provided with seed dispersal and seed dispersers are rewarded with nutritious food items (Vander Wall 1990). In various European ecosystems, Eurasian Jays (Garrulus glandarius; hereafter 'Jays') are the main seed removal vector for oaks (Quercus spp.) (Vander Wall 1990; Gómez 2003; Kurek

Communicated by F. Bairlein.

Aleksandra Wróbel

alekswrobel22@gmail.com

1 Department of Zoology, Poznań University of Life Sciences, Wojska Polskiego 71 C, 60-625 Poznań, Poland

2 Department of Plant Ecology and Environmental Sciences, Adam Mickiewicz University in Poznań, Umultowska 89, 61-614 Poznań, Poland

3 Department of Forest Ecology, Forest Research Institute, Braci Leśnej 3, 05-090 Sękocin Stary, Poland et al. 2018), whose seeds would not be effectively dispersed otherwise. In a year of high seed crop, a single Jay can scatterhoard (i.e., bury in shallow caches) thousands of acorns in a single season which improves acorn germination and oak recruitment (Vander Wall 1990). It is widely reported that dispersal and caching by Jays improves acorn germination and oak recruitment (Bossema 1979; Vander Wall 1990; Clayton et al. 1996; Kollmann and Schill 1996). However, seed hoarding requires cache-protection strategies which allow to protect hoarded seeds against pilferage. Here, we report the first case of acorn hoarding of both Pedunculate Oak (Quercus robur, native) and Northern Red Oak $(Q$. rubra, nonnative) by Jays in tree cavities.

\section{Methods}

For three weeks in November 2020, we were conducting research on dispersal of pedunculate oak and red oak acorns by Jays in managed forests in Zielonka Forest 
(western Poland). We used Telenax ${ }^{\mathrm{TM}}$ radiotransmitters inserted into each acorn, and were thus able to determine the exact fate of removed acorns (Kurek et al. 2018 for a similar approach). The acorns were offered during daytime (09:00-15:00) on seven feeders fixed on 1.5-m high poles and located at a distance of at least $1.2 \mathrm{~km}$ away from each other. Via direct observation, we could confirm that the only species removing the acorns was the Jay. Each feeder was visited by at least 1-6 Jays. Right after a Jay removed the acorn, we started radio-tracking to detect the seed and determine its fate (consumed vs. stored). The experimental acorns were usually found within few hours after removal. Moreover, the most abundant granivore rodent species in our study area was Yellow-necked Mouse (Apodemus flavicollis) which is nocturnal. This also helped us to exclude potential secondary dispersers, e.g. granivorous rodents, from re-caching of experimental acorns.

\section{Results and discussion}

We localized 14 consumed and 102 stored acorns (116 in total). Although most of stored seeds were hidden in either litter or the topsoil, five acorns of both oak species (two out of 65 for pedunculate oak and three out of 37 for red oak) offered at three different feeders were found stored in tree cavities. The stored acorns were additionally covered with a plug of hypnum moss (Hypnum cupresiforme) stacked in the tree hole (Fig. 1). Sticking the cache hole with plant material seems to be typical behavior for Jays (Kurek et al. 2018). In four cases, the acorns were located in four individuals of Black Locust (Robinia pseudoacacia, nonnative) (Fig. 2a, b). The black locusts had several visible cavities and their bark is highly furrowed in general (Fig. 2c). One recovered acorn was stored inside a rotten stem of Black Alder (Alnus glutinosa). The caches in trees were located at 1-7 $\mathrm{m}$ above the ground. Thus, up to $4.9 \%$ of cached acorns (five out of 102 acorns) were stored in trees. The precise location of one acorn was never found, but its signal suggested placement high up in the trees $(>7 \mathrm{~m})$, where we could not climb.
Fig. 1 The experimental acorn stored in tree cavity (a) covered with a plug of hypnum moss (Hypnum cupresiforme), and (b) uncovered (plug removed by the experimenter). The arrows show: the plug (yellow with crosses), the antenna protruding from the acorn (blue with stripes), and the experimental acorn (white with dots)
Fig. 2 Pictures (a) and (b): two of the four Black Locusts (Robinia pseudoacacia) used by Jays for acorn storage. c A closer view of a highly furrowed bark of black locust
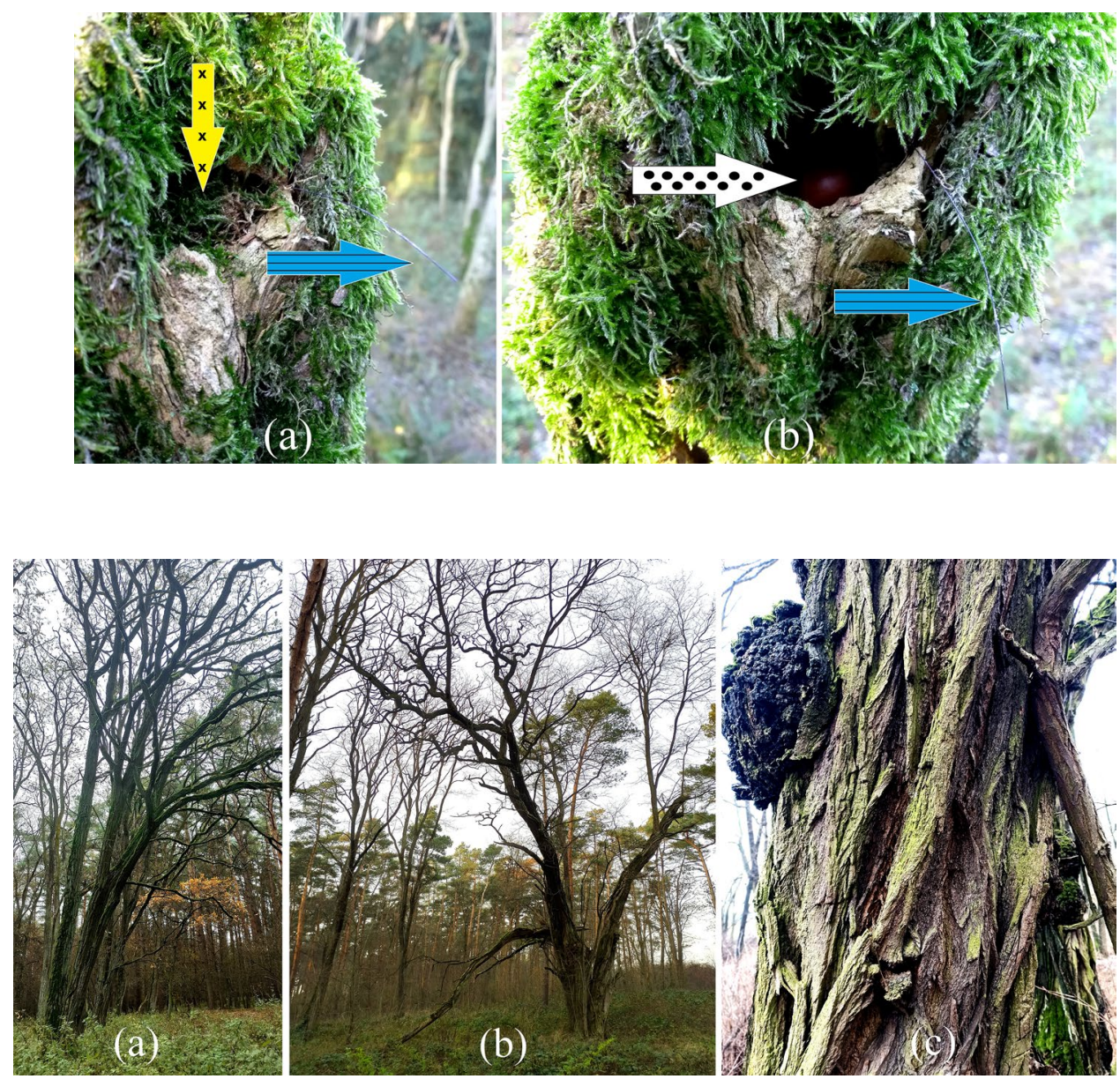
Some bird species, such as Blue Jays (Cyanocitta cristata) (Johnson et al. 1997), Eurasian Nutcrackers (Mattes 1982), and Acorn Woodpeckers (Melanerpes formicivorus) (Stacey 1981), hide nuts in trees and other vertical objects. However, seed hoarding in tree cavities has not been reported in Eurasian Jays before. Captive Eurasian Jays indeed stored acorns above the ground, between floor frames and on the ledges of aviaries (Clayton et al. 1996). While this suggests their propensity to store seeds in trees, to date, this behavior has not been observed in nature.

Acorns need to be placed either in litter or in contact with the mineral soil for development, while storing acorns in tree cavities precludes seedling establishment. Thus, from the plant perspective, storing acorns in trees is disadvantageous. Yet, it could bring noticeable benefits to Jays. Acorns are highly nutritious food items consumed not only by Jays but also by many other terrestrial animals foraging on the forest floor, including granivorous rodents and wild boars. This, in turn, generates extremely strong competition for acorns. Storing seeds in litter or soil creates a risk that the stored seeds will be pilfered. Indeed, ground-dwelling rodents are responsible for an extremely high proportion of pilfered seeds (Zwolak et al. 2016; Bogdziewicz et al. 2020). Hiding acorns in trees probably protects them from pilferage - at least to a degree, since some granivorous rodents can climb trees (e.g., Apodemus mice: Perea et al. 2011). Cacheprotection behavior of Jays are well studied. This includes limitation of opportunities for conspecifics to observe them (Shaw and Clayton 2012), reduction of the proportion of caches made in a noisy gravel substrate when a competitor can hear but cannot see them (Shaw and Clayton 2013), scatterhoarding single seeds in litter or soil (Bossema 1979; Gómez 2003; Kurek et al. 2018), and covering the caches with additional items such as leaves and pine cones (see Appendix 1 in Kurek et al. 2018). However, we propose that Jays store a certain proportion of seeds, dependent on availability of cavities, in trees to minimize seed loss of hoarded seeds. For example, higher densities of rodent pilferers, such as Apodemus mice whose abundances can increase to extremely high densities after several months of masting in some trees (Zwolak et al. 2016), will imply higher numbers of acorns hidden in tree cavities by Jays. This will require to determine the changes in Apodemus abundances when tracking seeds removed by Jays. If this hypothesis is true, then this behavior should be sensitive to the risk of pilferage by rodents, i.e., the proportion of acorns hidden in trees should drastically vary with small rodent abundances which are known to be highly fluctuating (e.g., Zwolak et al. 2016). We, however, do not expect that intraspecifc observers will increase the numbers of seeds hoarded in tree cavities as such seeds are easily available for Jays but not for mice. Nevertheless, another advantage of such behavior could be that access to tree caches is not limited by weather conditions during winter, e.g., deep snow cover. Jays storing acorns in trees also do not risk encountering terrestrial carnivores on the ground.

Considering the fact that cavities are crucial for storage in trees, this phenomenon has a potential to be more emphasized in forest stands with certain features associated with cavities, such as: (i) naturally flawed old trees, (ii) tree species with highly furrowed bark (e.g., black locust), (iii) activity of species responsible for forming tree cavities, e.g., woodpeckers, and/or iv) dead trunks. Moreover, although not measured in this study, it is also possible that seed transportation into tree cavities by Jays can be dependent on the size or shape of cavities. It is worth pointing out that our study was conducted in managed forests (40-60 yr-old) where the opportunities for seed hoarding in tree cavities may be rarer than in older or unmanaged stands (Remm and Lõhmus 2011), i.e., the proportion of acorns stored in trees may be higher due to higher microhabitat availability. Therefore, we also propose to ask the following question: is seed hoarding in tree cavities by Jays dependent on environmental features, such as type of the forest stands? If so, we believe that Jays will cache a higher proportion of seeds in tree cavities in unmanaged than in managed stands.

This study is first to demonstrate that Jays hide a certain proportion of acorns in trees which, we believe, may drastically vary between years with fluctuating granivorous rodent abundances and between different forest stands. Admittedly, our sample size was modest and the research was limited to one season and a restricted area within one managed and relatively young forest. Therefore, the notion that hoarding seeds in tree cavities may constitute a common behavior in Eurasian Jays represents a working hypothesis that ought to be tested in future studies. Such studies should determine what fraction of removed acorns is hidden in trees and which factors shape this behavior. Since hiding acorns in trees has not been observed or was ignored in previous studies, we urge researchers to pay increased attention to this phenomenon and its ramifications. Investigating the behavior of hoarding seeds in trees as an additional level of complexity to study of oak-Jay interactions will provide deeper insight into this well-established study system. This is needed for better understanding of seed dispersal processes per se, but also of consequences of forestry practices on forest regeneration, which are believed to alter features associated with tree cavities.

Acknowledgements We thank Forest District Łopuchówko for the permission to conduct the study and Rafał Zwolak for comments on this manuscript. AW was supported by (Polish) National Science Centre grant 'Sonatina' no. 2020/36/C/NZ8/00013.

Funding During the study, Aleksandra Wróbel was supported by (Polish) National Science Centre grant 'Sonatina' no. 2020/36/C/ NZ8/00013. 
Data availability The datasets used during the current study are available from the corresponding author on reasonable request.

Code availability Not applicable.

\section{Declarations}

Conflicts of interest The authors have no conflicts of interest to declare that are relevant to the content of this article.

Ethics approval No approval of research ethics committees was required to accomplish the goals of this study because experimental work did not include handling animals nor substantially affecting animals.

Open Access This article is licensed under a Creative Commons Attribution 4.0 International License, which permits use, sharing, adaptation, distribution and reproduction in any medium or format, as long as you give appropriate credit to the original author(s) and the source, provide a link to the Creative Commons licence, and indicate if changes were made. The images or other third party material in this article are included in the article's Creative Commons licence, unless indicated otherwise in a credit line to the material. If material is not included in the article's Creative Commons licence and your intended use is not permitted by statutory regulation or exceeds the permitted use, you will need to obtain permission directly from the copyright holder. To view a copy of this licence, visit http://creativecommons.org/licenses/by/4.0/.

\section{References}

Bogdziewicz M, Crone EE, Zwolak R (2020) Do benefits of seed dispersal and caching by scatterhoarders outweigh the costs of predation? An example with oaks and yellow-necked mice. J Ecol 1083:1009-1018. https://doi.org/10.1111/1365-2745.13307

Bossema I (1979) Jays and oaks: an eco-ethological study of a symbiosis. Behaviour 70:1-116. https://doi.org/10.1163/156853979X 00016

Clayton NS, Mellor R, Jackson A (1996) Seasonal patterns of food storing in the Jay Garrulus glandarius. Ibis 138:250-255. https:// doi.org/10.1111/j.1474-919X.1996.tb04336.x

Gómez JM (2003) Spatial patterns in long-distance dispersal of Quercus ilex acorns by Jays in a heterogeneous landscape. Ecography 26:573-584. https://doi.org/10.1034/j.1600-0587.2003. 03586.x
Johnson WC, Adkisson CS, Crow TR, Dixon MD (1997) Nut caching by blue Jays (Cyanocitta cristata L.): implications for tree demography. Am Mid Nat 2:357-370. https://doi.org/10.2307/2426828

Kollmann J, Schill HP (1996) Spatial patterns of dispersal, seed predation and germination during colonization of abandoned grassland by Quercus petraea and Corylus avellana. Vegetatio 125:193205. https://doi.org/10.1007/BF00044651

Kurek P, Dobrowolska D, Wiatrowska B (2018) Dispersal distance and burial mode of acorns in Eurasian jays Garrulus glandarius in European temperate forests. Acta Ornithol 53:155-162. https:// doi.org/10.3161/00016454AO2018.53.2.005

Mattes H (1982) Die Lebensgemeinschaft von Tannenhäher, Nucifraga caryocatactes (L.), und Arve, Pinus cembra L., b und ihre forstliche Bedeutung in der oberen Gebirgswaldstufe. Eidgenössische Anst für das forstliche Versuchswesen

Perea R, San Miguel A, Gil L (2011) Flying vs. climbing: Factors controlling arboreal seed removal in oak-beech forests. Forest Ecol Manag 262:1251-1257. https://doi.org/10.1016/j.foreco. 2011.06.022

Remm J, Lõhmus A (2011) Tree cavities in forests-the broad distribution pattern of a keystone structure for biodiversity. Forest Ecol Manag 262:579-585. https://doi.org/10.1016/j.foreco.2011.04.028

Shaw RC, Clayton NS (2012) Eurasian Jays, Garrulus glandarius, flexibly switch caching and pilfering tactics in response to social context. Anim Behav 84:1191-1200. https://doi.org/10.1016/j. anbehav.2012.08.023

Shaw RC, Clayton NS (2013) Careful cachers and prying pilferers: Eurasian Jays (Garrulus glandarius) limit auditory information available to competitors. P Roy Soc B: Biol Sci 280:20122238. https://doi.org/10.1098/rspb.2012.2238

Stacey PB (1981) Foraging behavior of the acorn woodpecker in Belize, Central America. The Condor 83:336-339. https://doi. org/10.2307/1367502

Vander Wall SB (1990) Food hoarding in animals. The University of Chicago Press

Zwolak R, Bogdziewicz M, Wróbel A, Crone EE (2016) Advantages of masting in European beech: timing of granivore satiation and benefits of seed caching support the predator dispersal hypothesis. Oecologia 180:749-758. https://doi.org/10.1007/ s00442-015-3511-3

Publisher's Note Springer Nature remains neutral with regard to jurisdictional claims in published maps and institutional affiliations. 